\title{
PERSEPSI WISATAWAN TERHADAP WISATA PANTAI DI KELURAHAN PECATU KABUPATEN BADUNG DALAM PERENCANAAN PAKET WISATA
}

\author{
Ida Bagus Made Widyasrama \\ I Made Kusuma Negara \\ I Wayan Suardana \\ Email : dyasrama@gmail.com \\ PS. S1 Industri Perjalanan Wisata \\ Fakultas Pariwisata UNUD
}

\begin{abstract}
This field study aims to determine the perception of tourists to the beaches in Pecatu Village Badung Regency. The results can be used to plan the tour packages according to tourist perceptions of the tourist beaches in Bali. Analysis techniques used in this research is the analysis of quantitative and qualitative. Analysis techniques in this study using quantitative descriptive.

Discussion of the results obtained in this study that the variables are extremely assessment given by tourists on beaches in Pecatu Village Badung Regency can already make tourists satisfied, must be maintained both management and development of the beaches, because there are still some variables that need to be addressed or equipped to make the tourists who come will still feel satisfied the beaches in Pecatu Village Badung Regency.

Results of this study on the perception of tourists to the beaches in Pecatu Village Badung Regency can be suggested to the travel industry as feedback in planning the manufacture of package tours. In addition to government and related managers, the results of this study can be a thought or input for the management and development of coastal tourism in accordance with the perception of tourists.
\end{abstract}

Keywords: Perception, Tourists, Planning Tour Package.

\section{PENDAHULUAN}

Pariwisata merupakan salah satu sektor yang digalakkan pemerintah dalam menambah devisa negara. Sektor ini diperhitungkan mengingat kegiatan pariwisata tidak dapat dipisahkan dari kehidupan manusia. Selain untuk menambah devisa negara, pembangunan pariwisata memiliki peran dalam meningkatkan pendapatan perekonomian masyarakat, meratakan kesempatan berusaha dan menciptakan peluang kerja. Selain itu, sektor pariwisata juga dianggap sebagai wadah dalam memperkenalkan kekayaan alam dan keanekaragaman budaya bangsa.

Sebagai salah satu destinasi tujuan wisata yang cukup terkenal di dunia, Bali merupakan salah satu daerah tujuan wisata di Indonesia yang memiliki potensi keindahan alam dan modal dasar untuk mengembangkan kepariwisataan. Keadaan geografis Bali yang berupa kepulauan dan langsung berhadapan dengan Samudra Indonesia, membuat Bali memiliki potensi alam yang dapat dikembangkan menjadi daya tarik wisata. Salah satu potensi alam di Bali yang dijadikan unggulan sebagai daya tarik wisata adalah wisata pantai yang ada di pesisir Bali Selatan. Berlokasi di Kelurahan Pecatu, Kabupaten Badung, ada beberapa pantai yang dapat digunakan sebagai tempat wisata, diantaranya adalah pantai Sluban, pantai Padang-padang, pantai Dreamland dan pantai Nyang-nyang. Berdasarkan observasi awal yang penulis lakukan, penulis mendapatkan sebuah fenomena dari beberapa wisatawan yang datang ke Bali, yaitu mereka lebih suka melakukan 
dibandingkan wisata lainnya yang ada di Bali. Namun, hingga saat ini, masih sangat minim paket wisata yang sesuai dengan wisatawan yang lebih menyukai wisata pantai di Bali. Oleh karena itu, penulis bermaksud melakukan sebuah penelitian mengenai persepsi wisatawan terhadap wisata pantai di Kelurahan Pecatu Kabupaten Badung yang hasil dari penelitian ini nantinya untuk mengetahui bagaimana persepsi wisatawan yang lebih menyukai wisata pantai dibandingkan dengan destinasi wisata lainnya yang ada di Bali sebagai perencanaan paket wisata baru.

\section{TINJAUAN PUSTAKA}

Rangkuti (2009) menjelaskan bahwa persepsi adalah proses yang digunakan oleh seorang individu untuk memilih, mengorganisasi dan menginterprestasi masukan-masukan informasi guna menciptakan gambaran dunia yang memiliki arti.

Suwena dan Widyatmaja (2010) menjelaskan bahwa wisatawan adalah 1) mereka yang melakukan kunjungan yang mengikuti perjalanan kapal laut, walaupun tinggal kurang dari 24 jam. 2) mereka yang mengadakan perjalanan untuk tujuan usaha. 3) mereka yang mengadakan perjalanan untuk keperluan senang-senang, mengunjungi keluarga dan lain-lain.

Weiler dan Colin (1992) menjelaskan bahwa wisata minat khusus bertumpu pada dua hal pokok, yakni : 1. Novelty seeking, yaitu motivasi pada pencarian terhadap objek dan daya tarik wisata yang unik dan baru. Atau pencarian/ eksploitasi terhadap lokasi-lokasi baru yang lebih menantang untuk jenis atraksi wisata yang diamati, 2. Quality seeking, yaitu motivasi pada pencarian terhadap bentukbentuk objek dan daya tarik wisata yang mampu memberikan nilai manfaat yang berarti bagi wisatawan, nilai pengkayaan atau pengembangan diri (enriching), nilai tantangan atau petualangan, serta pengetahuan wawasan baru.

Pantai adalah perbatasan antara daratan dengan laut, sedangkan laut adalah kumpulan air dalam jumlah banyak yang membagi daratan atas benua-benua dan pulau-pulau. Jadi wisata pantai dapat diartikan sebagai wisata yang memanfaatkan potensi sumber daya pantai beserta komponen pendukungnya, baik alami maupun buatan atau gabungan

\section{METODE PENELITIAN}

Penelitian ini dilakukan di pantai Sluban, pantai Padang-padang, pantai Dreamland dan pantai Nyang-nyang yang berlokasi di Kelurahan Pecatu, Kabupaten Badung. Penelitian ini memfokuskan kepada 3 hal yaitu, karakteristik wisatawan yang datang ke wisata pantai, persepsi terhadap destinasi wisata pantai yang dibagi menjadi 2 analisis, yaitu kuantitatif (fisik dan non fisik) dan kualitatif (pendapat wisatawan) serta perencanaan paket wisata. Pengumpulan data dilakukan dengan cara observasi, kuisioner dan studi kepustakaan. Penelitian ini merupakan penelitian kuantitatif deskriptif. Untuk mengukur atau pemberi skor pada setiap indikator pada pernyataan kuesioner menggunakan skala Likert. Teknik penentuan sampel ditentukan dengan metode purposive sampling. Sedangkan untuk menetapkan ukuran sampel minimal dari suatu populasi yang diketahui dengan menggunakan rumus Slovin.

Berdasarkan hasil penghitungan yang telah dilakukan, maka ukuran sampel minimal yang digunakan penulis untuk menentukan jumlah responden dalam menjawab kuesioner adalah 100 orang responden.

\section{HASIL DAN PEMBAHASAN}

Sebagian besar wisatawan yang berkunjung ke Wisata Pantai di Kelurahan Pecatu Kabupaten Badung berusia 20-30 tahun, berjenis kelamin wanita, serta jenis pekerjaannya adalah wiraswasta dan mahasiswa/siswa.

Variabel keadaan wisata pantai dapat diketahui kebersihan wisata pantai merupakan indikator tertinggi dari penilaian wisatawan dengan total skor 432, sedangkan untuk variabel akses masuk wisata pantai, indikator tertinggi adalah kemudahan mencari wisata pantai tersebut dengan total skor 325 .

Variabel kenyamanan wisatawan dapat diketahui jika indikator tertinggi dari penilaian wisatawan adalah kelengkapan sarana dan prasarana dengan total skor 391. Untuk variabel keamanan di wisata pantai, indikator tertinggi yang diberikan adalah pengawasan dari life guard dengan total skor 398, sedangkan variabel mengenai informasi wisata pantai, indikator tertinggi yang diberikan adalah petunjuk arah yang mendukung dengan skor 369 dan variabel mengenai 
tertinggi yang diberikan adalah pengembangan sarana yang mendukung dengan skor 340 .

Dari hasil analisis kuantitatif dan kualitatif pada bahasan sebelumnya, dapat diketahui jika perencanaan paket wisata yang dapat dibentuk sesuai dengan penilaian yang telah diberikan oleh wisatawan adalah merencanakan paket wisata dengan destinasi wisata pantai yang terjaga kebersihannya, berbeda dengan wisata pantai di daerah lain dan rambu larangan untuk membawa bendadbenda yang dapat merusak lingkungan wisata pantai. Selain itu perencanaan paket wisata yang dapat dibentuk adalah membuat wisatawan yang dapat melakukan aktivitas di wisata pantai tersebut, seperti berenang, bermain kano, berfoto-foto, snorkeling, Perencanaan paket wisata yang dapat dibuat juga harus memperhatikan keamanan dan kenyamanan seperti kesigapan life guard dan pemasangan rambu peringatan ombak besar. Hal tersebut dapat membuat wisatawan betah berlama-lama di wisata pantai tersebut dan merencanakan untuk membuat paket wisata ke destinasi wisata pantai yang telah memiliki atau berpotensi untuk melengkapi fasilitas maupun sarana dan prasarana yang mendukung bagi wisatawan, namun tidak merusak lingkungan wisata pantai yang dapat menghilangkan kealamian wisata pantai tersebut.

\section{SIMPULAN DAN SARAN Simpulan}

Berdasarkan pada analisis dan uraian yang telah dijelaskan maka hasil penelitian ini dapat disimpulkan bahwa indikator penilaian yang sangat diperhatikan oleh wisatawan adalah kebersihan yang terjaga pada wisata pantai dan pengawasan dari life guard untuk menjaga keamanan wisatawan ketika berada di wisata pantai. Dari penilaian akan indikator lainnya, seperti rambu larangan untuk membawa benda yang dapat merusak wisata pantai, kelengkapan sarana dan prasarana, petunjuk arah yang mendukung mengenai lokasi wisata pantai dan pengembangan wisata juga merupakan penilaian yang diperhatikan wisatawan ketika mengunjungi wisata pantai. Selain itu, pengelolaan maupun pengembangan wisata pantai harus tetap dijaga dengan baik, karena masih ada beberapa variabel yang perlu dibenahi ataupun dilengkapi untuk membuat wisatawan yang datang tetap merasa puas.

Sehingga perencanaan paket wisata yang dapat dibentuk sesuai dengan persepsi wisatawan pecinta pantai adalah dengan memperhatikan kebersihan yang terjaga pada wisata pantai, pengawasan dari life guard menjaga keamanan serta membuat wisatawan yang dapat melakukan aktivitas di wisata pantai tersebut, seperti berenang, bermain kano, berfoto-foto, snorkeling.

\section{Saran}

Bagi para pelaku industri perjalanan wisata, hasil penelitian ini dapat digunakan untuk menjadi bahan masukan atau saran dalam merencanakan paket wisata bagi para pecinta wisata pantai di Bali. Sedangkan bagi pengelola ataupun pemerintah terkait, hasil penelitian ini dapat digunakan sebagai bahan masukan atau saran untuk pengelolaan untuk wisata pantai yang ada di Kelurahan Pecatu Kabupaten Badung. Pengembangan dapat dilakukan dengan maksimal, namun kealamian dan kebersihan wisata pantai merupakan prioritas utama wisatawan mendatangi wisata. Selain itu, dari kesimpulan yang di dapat, penilaian tertinggi dari wisatawan akan wisata pantai Kelurahan Pecatu Kabupaten Badung dapat digunakan sebagai bahan prioritas utama yang dapat dilakukan untuk mengembangkan wisata pantai demi menjaga keamanan, kenyamanan wisatawan ketika berada di wisata pantai.

\section{DAFTAR PUSTAKA}

\section{Hendra. 2013. Jenis-jenis Penelitian dan} Penarikan Sampel. From http://hendramarambak.blogspot.com/20 13/03/jenis-jenis-penelitian-danmetode.html

Rangkuti, Freddy. 2009. Strategi Promosi Yang Kreatif dan Analisis Kasus Integrated Marketing Communication. Jakarta: PT. Gramedia Pustaka Utama

Simond, John O., 1978, Eartscape, New York: McGraw Hill Book Company

Suwena, I Ketut, I Gst Ngr Widyatmaja. 2010. Pengetahuan Dasar Ilmu Pariwisata. Denpasar: Udayana University Press.

Weiler, Bety dan Collin. 1992. Special Interest Tourism. London : Bellhaven Press. 